\title{
Photovoltaic Solar Spectral Filtering Using Bio-Filters
}

\author{
Moses E. Emetere \\ Department of Physics, \\ Covenant University Canaan land, \\ P.M.B 1023, Ota, Nigeria; \\ Department of Mechanical Engineering Science, \\ University of Johannesburg, South Africa
}

Doi: 10.36941/ajis-2020-0o13

\section{Abstract}

The harsh solar irradiance measurement in recent times has further supported the existence of global climate change. It is not clear if this challenge is located in other parts of the world. Over the years, it has been observed that PV panel have a lower lifespan with a failing performance. Due to the peculiarity of this challenge in the research, the bio-filter was synthesized to shield the PV panel from damage via the aforementioned harsh solar radiation. The bio-filter was tested using the monocrystalline and polycrystalline panel. The results proved that the bio-filters are good stabilizing medium.

Keywords: Solar energy, solar, spectral filtering, photovoltaic, bio-filter

\section{Introduction}

The solar energy option is widely used because it is environmentally friendly and its source is sustainable (Emetere et al., 2018). The Africa solar energy market initially had a big boost when prices of photovoltaic panels were slashed (Oxy, 2019). This made it affordable for domestic and large-scale users to purchase at will. After five years of sustained PV prices, the Africa solar market ought to be stimulated. However, the PV patronage was grossly mitigated since users have to buy PV panels within short time of purchase. This challenge is not peculiar to a product of the PV sold in the Markets. A typical example of the low-performing PV panels is the downward production of solar grid power between 2016 to date (Schmela et al. 2019). Based on the above research problem, the author proposed the use of filters that will be optically adequate to severe unwanted radiation wavelength. This process is called spectra filtering.

The various types of spectral filters include dichroic filters and light filters (Edmund, 2019). A light filter is a transparent filter that attenuates light (or some wavelengths of light) passing through it. A dichroic filter is an accurate colour filter used to selectively pass light of a small band of colors while reflecting other colours (Reichman, 2000). Solar cells operate within the different spectrum of visible light. The infrared spectrum is largely responsible for heat and this heat is not needed on solar cells since they have a working temperature which should not be more than $35^{\circ} \mathrm{C}$ to $45^{\circ} \mathrm{C}$ depending on panel type; this means any temperature below this would result in critical failure of the solar panels. During STC (standard test conditions) the temperature used for test is $25^{\circ} \mathrm{C}$ this implies that even $35^{\circ} \mathrm{C}-45^{\circ} \mathrm{C}$ is still on a high side (Energysage, 2019; Dubey et al., 2013). From the above, it can be 
inferred that there are harsh solar radiation that reduce the efficiency of solar PV panel by damaging its solar cells.

One of the criteria of a good filter is its ability to absorb as much of the Infrared spectrum as it can while allowing visible light to pass through thereby reducing the temperature of the solar panel and increasing its efficiency (Christi et al. 1999). In this research a bio-filter is proposed to perform spectra filtering. The pigment in plant leaves extract has been found to strongly absorb visible light and reflects near infrared. Near infra-red has the highest energy in the infra-red spectrum (Li et al., 2010).

In this research, Ixora coccinea Linn (Rubiaceae) extract was used as the bio-optical filter. Ixora is known in different regions of the earth with many names such as: Jungle of Geranium, West Indian Jasmine, Ponna,Flame of the woods, vetchi in Ayurveda, Rangan, Kheme etc. Ixora coccinea Linn is flowering plant that belongs to the Rubiaceae family. This plant is common in Africa, Southern Asia and some parts of India. The Ixora plant possesses high medicinal value (Dontha et al. 2015). The Ixora plant is one of the most research plants (Nayak et al., 1999; Faten et al., 2003; Yasmeen and Prabu, 2011). The ixora extract was synthesized with copper so as to alter the optical properties of the extract to act as bio-filter.

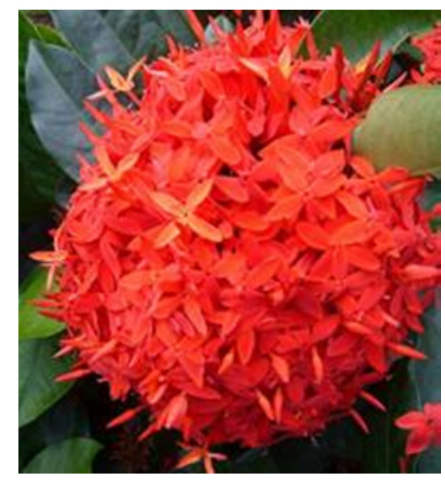

Figure 1: Ixora coccinea Linn (Rubiaceae)

\section{Materials and Methods}

The spectra selection was first carried in the dark room using: three $3 \mathrm{~W}$ Monocrystalline solar panels; three $4 \mathrm{~W}$ polycrystalline solar panels; $2 \mathrm{~mm}$ Connecting wires; data logger; digital Multimeter; retort stand, solarimeter; halogen lamp; colour filters; and liquid solid filter. The rating of the monocrystalline solar panel is: nominal peak power $(+-3 \%)(\mathrm{pmax})=3 \mathrm{w}$; open circuit voltage (voc) $=10.8 \mathrm{v}$; short circuit current $($ isc $)=418 \mathrm{~mA}$; maximum power voltage $(\mathrm{vmp})=8.2 \mathrm{v}$; maximum power current $(\mathrm{imp})=366 \mathrm{~mA}$; and standard test conditions $=1000 \mathrm{~W} / \mathrm{M} 2.25 \mathrm{C}$ AM1.5. The rating of the polycrystalline solar panel is: nominal peak power $(+-3 \%)(\mathrm{pmax})=4 \mathrm{~W}$; open circuit voltage $(\mathrm{Voc})=$ 22.466V; short circuit current (Isc) $=0.235 \mathrm{~A}$; maximum power voltage $(\mathrm{Vmp})=18.436 \mathrm{~V}$; maximum power current $(\operatorname{Imp})=0.220 \mathrm{~A}$; standard test conditions $=100 \mathrm{~W} / \mathrm{m} 2.250 \mathrm{C}$ AM1.5.

The panels were connected in series. The angular positioning of the panels to the light source was enabled by the retort stand. The solarimeter was used to measure the amount of radiation produced by the halogen lamp and the different colour filters were used to do the spectra filtering of light incidental on the solar panel. The angle of inclination of the panel to the light source was varied.

The Ixora coccinea Linn flower was blended with ethanol and filtered. The filtrate collected into a beaker. The $10 \mathrm{ml}$ of the filtrate was mixed with 0.0045 mole of $\mathrm{Cu}\left(\mathrm{NO}_{3}\right)_{2} \cdot 3 \mathrm{H}_{2} \mathrm{O}$ and left a day to enable proper dissolution of copper.Ixora coccinea flower is of ursolic acid chemotype (Elumalai et 
al., 2012) that is structurally presented in Figure 2.

The data logger can accommodate six panels but four panels were used (Figure 3) in total (two monocrystalline and two polycrystalline). One monocrystalline and polycrystalline panel was unsprayed and the other two panels (monocrystalline and polycrystalline) were sprayed. The unsprayed panels were used as control mechanism to monitor the sprayed panels.

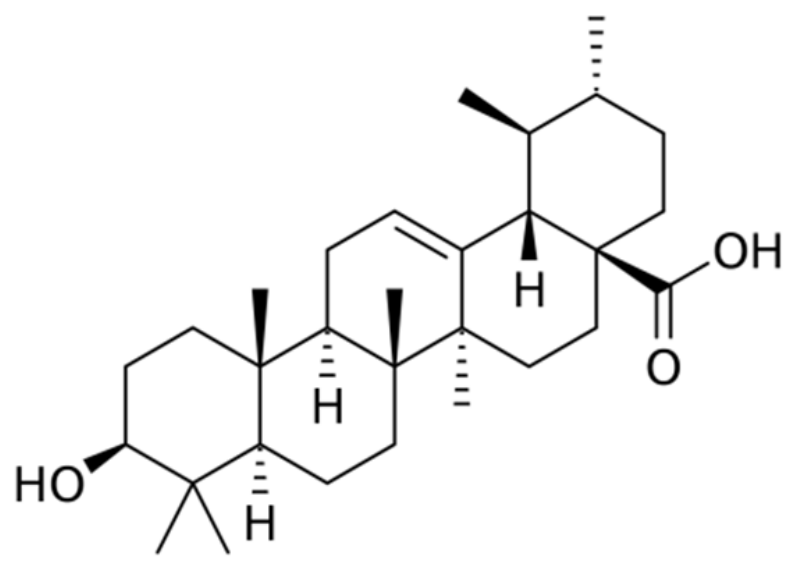

Figure 2: Ursolic acid in Ixora coccinea Linn

Before the panels were sprayed, it was cleaned with distilled water. The panels were afterwards put under the sun and the readings from the panels were recorded on the logger and stored in an SD card.

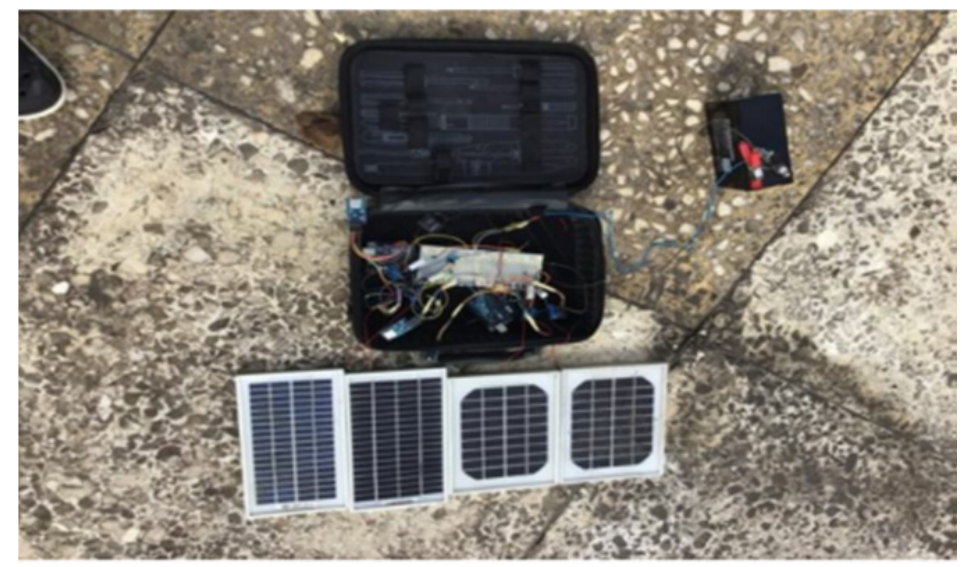

Figure 3: Experimental set-up of sprayed and unsprayed PV panel

\section{Results and Discussion}

The structural formations of the synthesized copper coated Ixora extract is presented in Figure 4. Figure shows six planes along the a-c axes. The copper lelement is located at the boundary of the planes. This atomic position makes it possible for the copper coated ixora extract to have higher optical properties. Along the a-b axes, the matrix of the bio-filter shows the salient role played by oxygen element. Figure $3 \mathrm{c}$ shows that the hydrogen element is the connecting 

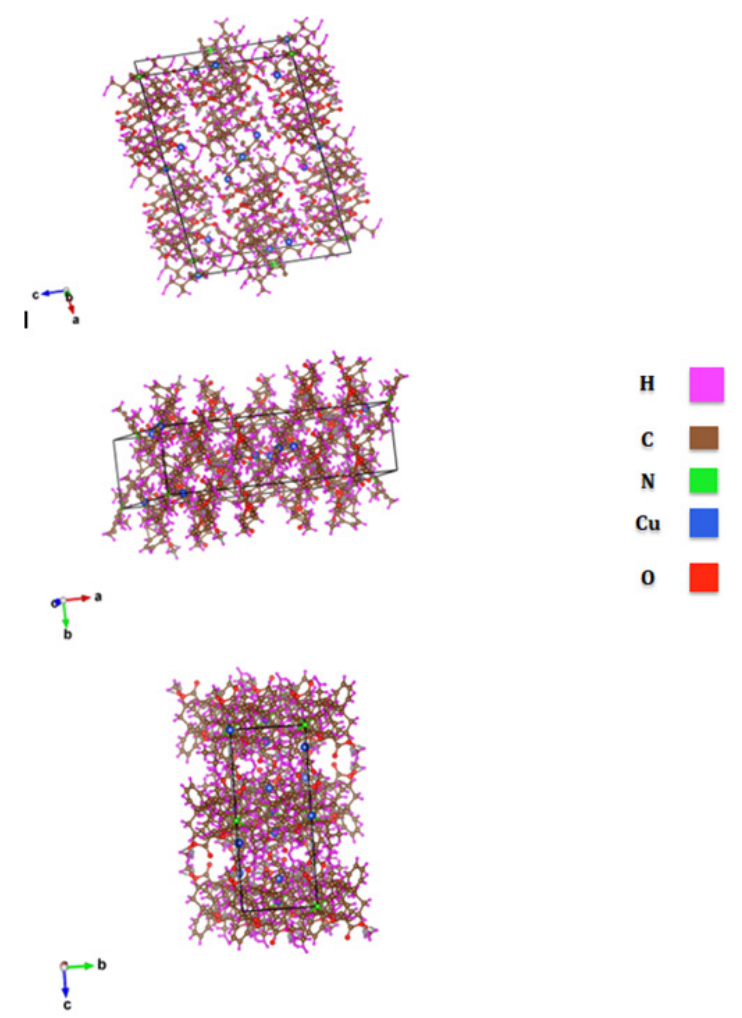

Figure 3: Structures of copper coated Ixora extract link between the bulk sample. The XRD of the sample reveals that bio-filter is an optical device with peaks showing the presence of crystalline planes (Figure 4).

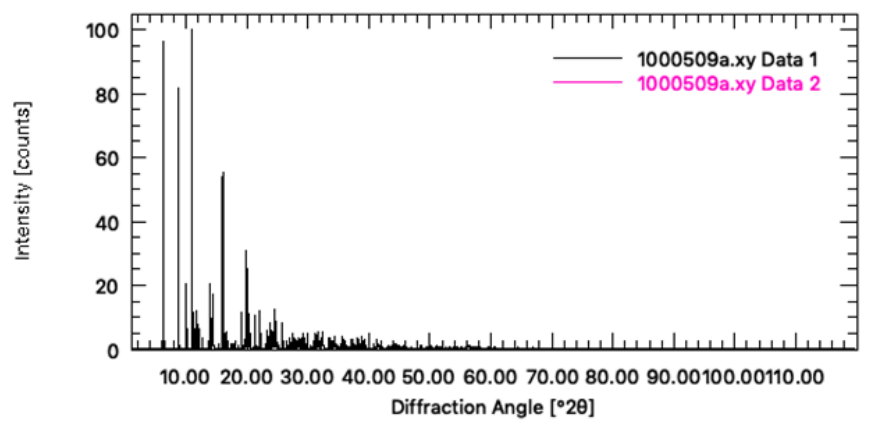

Figure 4: XRD of copper coated Ixora extract

The analysis of the peaks in Figure 4 is presented in Table 1. Plane [110] has the highest peak. The close peaks at plane [200] and [002] are typical evidence of the bio-filters ability to reflect unwanted wavelength. The X-ray dispersion coefficients for each element at $\lambda=0.154432 \mathrm{~nm}$ is presented in Table 2. The copper and hydrogen element are seen to play significant role in the optical properties of the synthesized bio-filter. 
Table 1: Quality of peaks in Figure 4

\begin{tabular}{ccccc}
\hline hkl & $\mathrm{d}$ & $(\AA)$ & $|\mathrm{F}|$ & $2 \theta$ \\
\hline 2 o o & 13.892434 & 421.733119 & 6.35704 & 75.80548 \\
o o 2 & 10.043373 & 573.352706 & 8.79747 & 72.90825 \\
2 o -2 & 8.767675 & 341.183369 & 10.08060 & 19.63334 \\
11 o & 7.996872 & 597.785972 & 11.05514 & 100.00000 \\
$31-2$ & 5.522930 & 709.275405 & 16.03464 & 66.13432 \\
6 o -2 & 4.459385 & 965.933089 & 19.89387 & 39.36468 \\
\hline
\end{tabular}

Table 2: X-ray dispersion coefficients for $\lambda=0.154432 \mathrm{~nm}$

\begin{tabular}{|c|c|c|c|c|}
\hline Element & $f^{\prime}$ & $\mathrm{f}^{\prime \prime}$ & f_NT & $\mu / \rho\left(\mathrm{cm}^{\wedge} 2 / \mathrm{g}\right)$ \\
\hline O: & $4.79422 \mathrm{E}-\mathrm{O} 2$ & $3.21995 \mathrm{E}-\mathrm{O} 2$ & $-2.19440 \mathrm{E}-\mathrm{O} 3$ & $1.10532 \mathrm{E}+\mathrm{O} 1$ \\
\hline$C:$ & $1.78642 \mathrm{E}-\mathrm{O} 2$ & $9.09998 \mathrm{E}-03$ & $-1.64420 \mathrm{E}-\mathrm{O} 3$ & $4.33550 \mathrm{E}+\mathrm{oo}$ \\
\hline $\mathrm{H}:$ & $1.00136 \mathrm{E}-05$ & $1.08282 \mathrm{E}-06$ & $-5.44230 \mathrm{O}-\mathrm{O} 4$ & 3.84157 E-O1 \\
\hline $\mathrm{N}:$ & $3.08381 \mathrm{E}-02$ & $1.81499 \mathrm{E}-\mathrm{O} 2$ & $-1.91910 \mathrm{E}-03$ & $7.22063 \mathrm{E}+\mathrm{oo}$ \\
\hline $\mathrm{Cu}:$ & $-2.00539 \mathrm{E}+00$ & $5.85814 \mathrm{E}-\mathrm{O} 1$ & $-7.26020 \mathrm{E}-03$ & $5.04099 \mathrm{E}+01$ \\
\hline
\end{tabular}

The laboratory spectra filtering were carried out in the dark room using the filters mentioned in the previous section. The outcome of the power generation in the dark room is presented in Figure 4. The yellow and blue filter had same trend as the combined filters. These shows that yellow and blue wavelength could influence the power trend of a solar panel. The yellow filter was particularly impressive because it had the highest power generation among the individual filters. The blue filter has the lowest power generation. The results agrees with past research work (Elvado et al., 2017; Bobby, 2015).
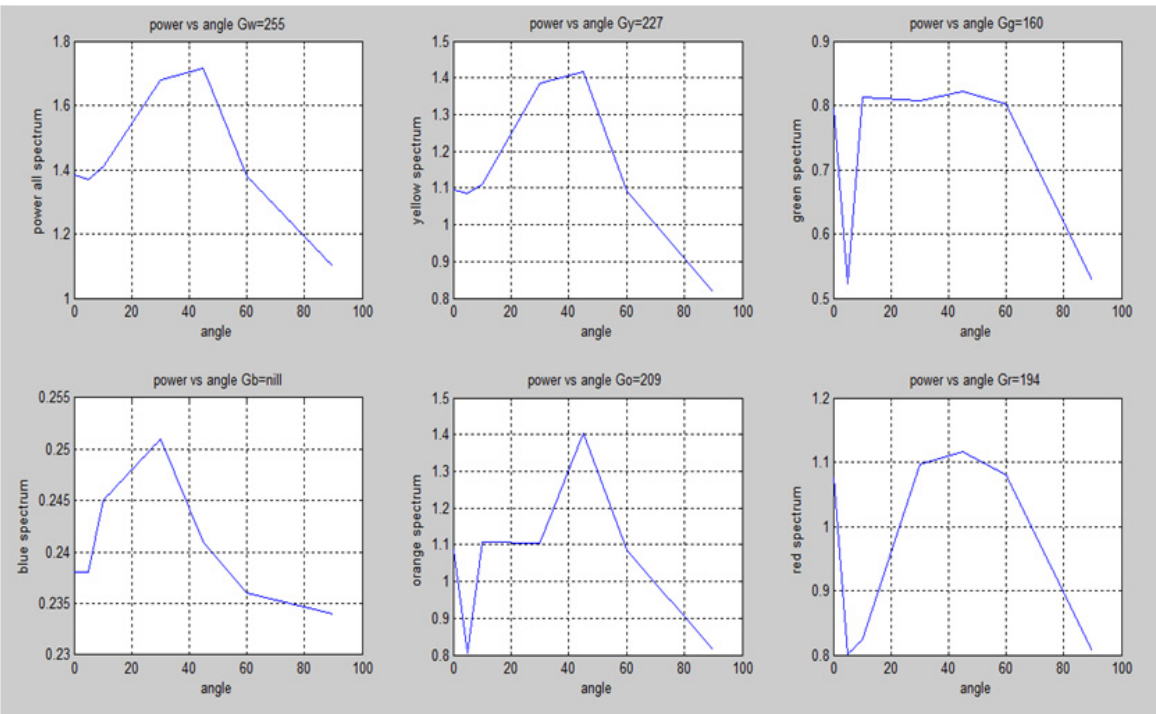

Figure 4: Comparison of Power against angle for different spectrum of visible light

Figure 4 presents the solar radiation against time in the coated or sprayed panel. It was observed that the radiation rises in a stepwise manner. Thick lines represent rapid fluctuations in radiation within the given time interval. 


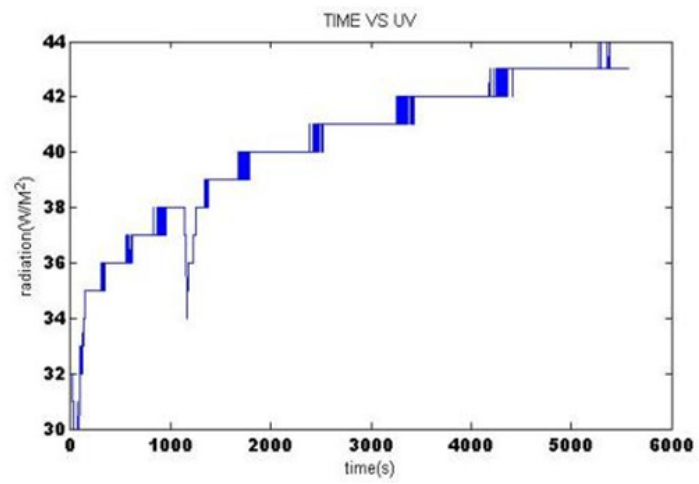

Figure 5: Radiation signatures of sprayed monocrystalline panel

It was also observed that while the solar radiation increases linearly, the temperature distribution reduces with time (Figure 6). This means that the bio-filter was able to screen the thermal flow from the sun.

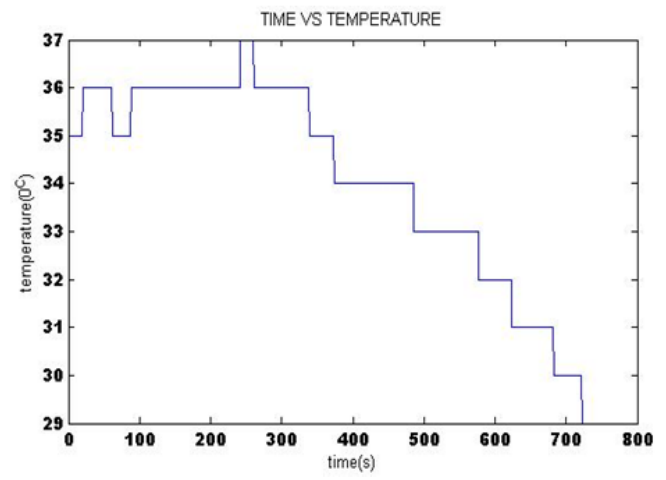

Figure 6: Temperature distribution of sprayed monocrystalline panel

Figure 7 presents current against time for the sprayed (current2) and unsprayed panels (current1). Current of the sprayed panel was higher than the unsprayed panel. It is generally observed that the current decreases to o.1 A where both current intercepts. In comparism to the temperature distribution (Figure 6), it can be concluded that panel is more stable at lower temperature.

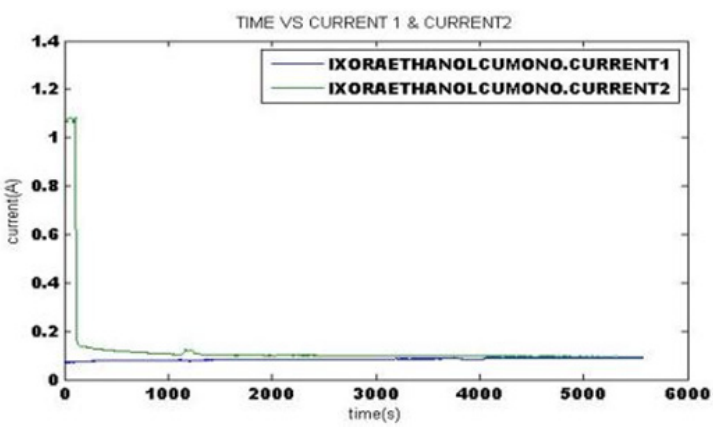

Figure 7: Current vs time of sprayed and unsprayed monocrystalline panel 
Figure 8 below is a graph of voltage against time of the sprayed and unsprayed panel. The voltage in the sprayed panel (voltagez) was observed to be lower than that of the unsprayed panel. Both voltages show stepwise increase. Thick lines represent rapid fluctuations. It could be seen that the bio-filter in the sprayed panel could stabilize voltage output.

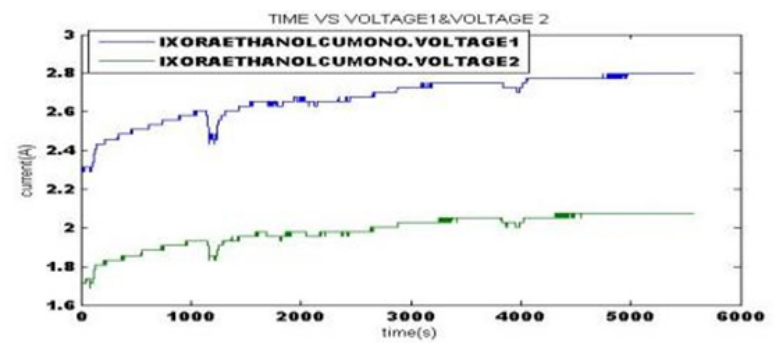

Figure 8: Voltage vs time of sprayed and unsprayed monocrystalline panel

Figure 9 below shows a graph of power against time for the unsprayed (powerı) sprayed panel (power2). It shows a very high difference in the power of the sprayed panel to that of the unsprayed panel. Power of the sprayed panel started decreasing until it came to point where power of the sprayed panel was lower than that of the unsprayed panel. The initial spike may be as a result of the high temperature at the time the measurement was taken.

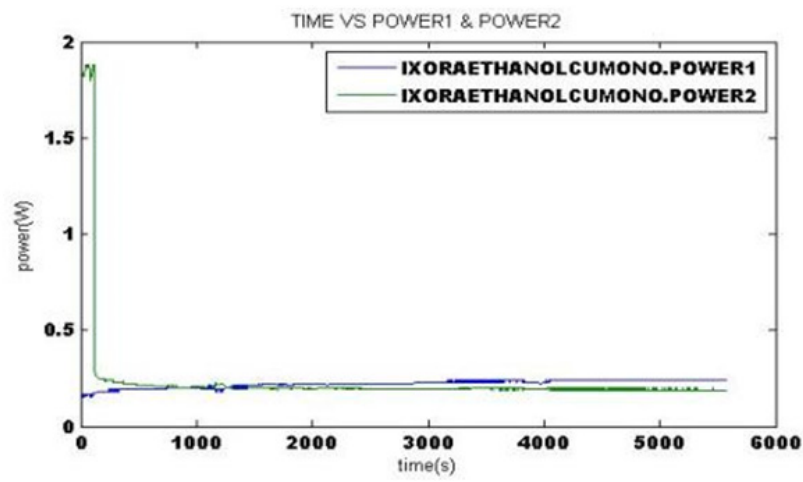

Figure 9: Power vs time of sprayed and unsprayed monocrystalline panel

Figure 10 presents the radiation against time in the polycrystalline panel. The radiation is almost stable for a long period with minor fluctuation.

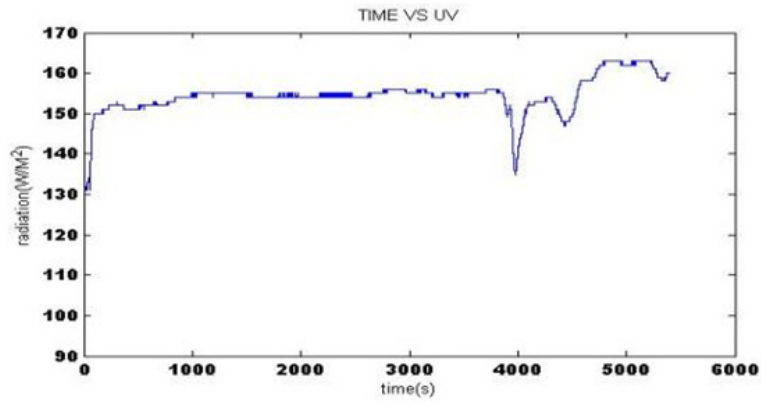

Figure 10: Radiation signature in sprayed polycrystalline panel 
Figure 11 below shows the temperature distribution over the polycrystalline panel. It was observed that the sunosoidal nature of the temperature was stabilized as presented in Figure 11.

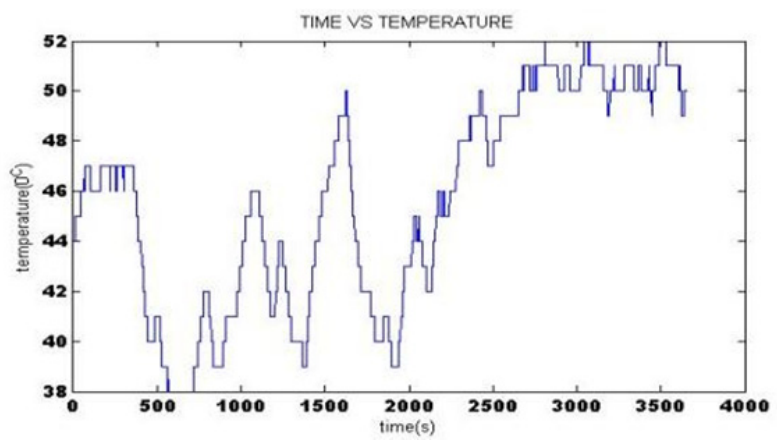

Figure 11: Temperature distribution of sprayed polycrystalline panel

Figure 12 below shows Current against time of the unsprayed (current3) and unsprayed (current 4) panels. The current generation for both panels were almost the same. However, it was observed that bio-filter on the sprayed panel was able to stabilize the current generation in the panel.

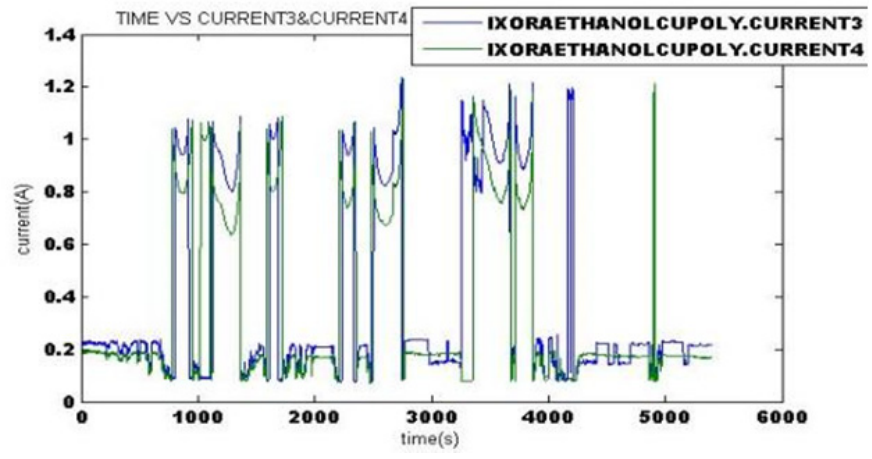

Figure 12: Current against time of sprayed and unsprayed polycrystalline panels

Figure 13 below shows the graph of voltage against time of the sprayed (voltage4) and unsprayed (voltage3) panel. Voltage in the sprayed panel was lower than that of the unsprayed panel. However, it was observed that thick lines, which represent rapid fluctuations, were almost stabilized.

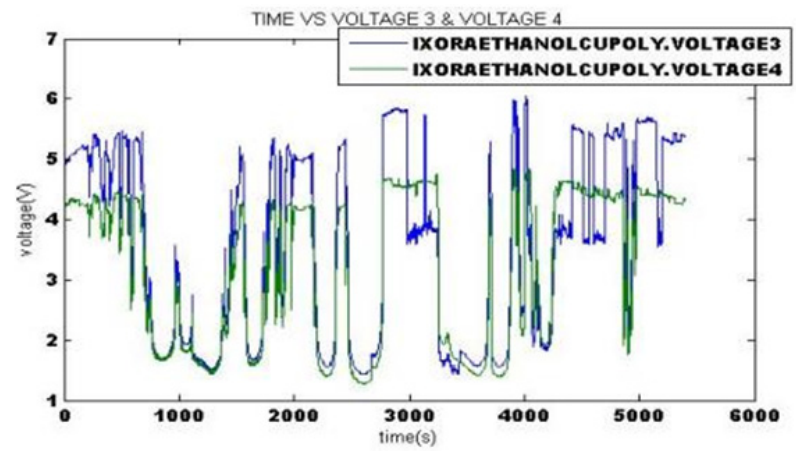

Figure 13: Voltage against time of sprayed and unsprayed polycrystalline panels 
Figure 14 below shows the power generated in the unsprayed (power3) and sprayed (power4) panel. It is observed that the power generated in the unsprayed panel was higher than that of the sprayed panel.

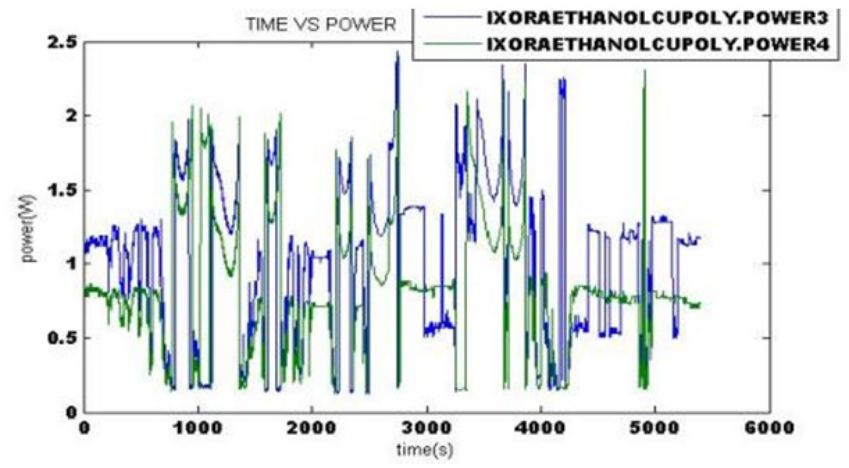

Figure 14: Power against time of sprayed and unsprayed polycrystalline panels

\section{Conclusion}

The bio-filter has shown tremendous results. It could filter and stabilize measured parameter. The adoption of the bio-filter (copper coated ixora-ethanol extract) showed better results in the monocrystalline. However, the outcome in the polycrystalline panel is novel for adoption. In other words, bio-filter are very efficient as spectra filtering agent for PV panels in the tropics. Further research is recommended to understand the lifespan of the bio-filter, as its shelf life was approximately a month.

\section{References}

Bobby Garces (2015). https://sites.suffolk.edu/bobbyg3142/2015/11/11/solar-power-how-different-colors-anddistances-affect-voltage/ (Accessed 23/07/2019).

Dontha S, Kamurthy H and Manthripragada B: Phytochemical and Pharmacological Profile of Ixora: A Review. Int J Pharm Sci Res 2015; 6(2): 567-84

Dubey, S., Sarvaiya, J.N. and Seshadri, B. (2013) Temperature Dependent Photovoltaic (PV) Efficiency and Its Effect on PV Production in the World: A Review. Energy Procedia, 33, 311-321.

Edmund, (2019). https://www.edmundoptics.com/resources/application-notes/optics/optical-filters/ (Accessed 23/07/2019)

Elumalai A., Chinna Eswaraiah, Yetcharla Venkatesh, Burle Shiva kumar and Chava Narendar, Phytochemical and pharmacological profile of Ixora coccinea Linn, International Journal of Pharmacy \& Life Sciences, 3(3): 15631567

Evaldo C. Gouvêa *, Pedro M. Sobrinho and Teófilo M. Souza, (2017). Spectral Response of Polycrystalline Silicon Photovoltaic Cells under Real-Use Conditions, Energies, 10,:1178

Emetere M., S Sanni, O Dauda, A Akinsiku, O Osunlola, A Adejumo, (2019). Operational Trends of a mini parabolic solar collector for agricultural purposes in a non-active solar environment, Journal of Computational \& Applied Research in Mechanical Engineering 15:4

Energysage, (2019). https://news.energysage.com/solar-panel-temperature-overheating/ Accessed 23/o7/2019)

Faten MM Darwish and Zedan Z Ibraheim: Phytochemical Study of Ixora finlaysoniana Ex. G. Don growing in Egypt. Bull. Pharm. Sci. 2003; 26(1): 91-96

Liu F., D. Deng, X. Chen, Z. Qian, S. Achilefu, and Y. Gu, (2010), Folate-polyethylene glycol conjugated nearinfrared fluorescence probe with high targeting affinity and sensitivity for In vivo early tumor diagnosis, Molecular Imaging and Biology, 12: 595-607. istep? 
Nayak B.S, Udupa A.L, Udupa S.L. (1999). Effect of Ixora coccinea flowers on dead space wound healing in rats, Fitoterapia, $70(3): 33-236$

Oxy, (2019). https://www.ozy.com/fast-forward/africa-embraces-an-8-billion-solar-market-for-going-offgrid/92303 (Accessed $19^{\text {th }}$ July, 2019).

Reichman J., Handbook of Optical Filters for Fluorescence Microscopy, Chroma Technology Corp., Brattleboro, Vt, USA, 2000.

Schmela Michael, Aurélie beauvais, Naomi Chevillard, Mariano Guillén Paredes, Máté Heisz, Raffaele Rossi, Michael Schmela, SolarPower Europe et al. (2019). Global Market Outlook For Solar Power / 2018 - 2022, http://www.solarpowereurope.org/wp-content/uploads/2018/o9/Global-Market-Outlook-2018-2022.pdf (Accessed $19^{\text {th }}$ July, 2019).

Yasmeen Maniyar and Prabu Bhixavatimath. (2011). Evaluation of the Hypoglycaemic and Hypolipidaemic Activities of the Aqueous Extract of the leaves of Ixora coccinea Linn in Diabetic Rats. Journal of Clinical and Diagnostic Research. 5(7): 1381-1384 